DIAJAR: Jurnal Pendidikan dan Pembelajaran
https://journal.yp3a.org/index.php/DIAJAR
ISSN Media Elektronik xxxx-xxxx
Vol. 1 No. 1 (Januari 2022) 100-105
DOI: xxxxx

\title{
Pengembangan Critical Thinking Dalam Peningkatan Mutu Pendidikan di Indonesia
}

\author{
Atris Yuliarti Mulyani \\ Teknologi Pendidikan, Fakultas Ilmu Pendidikan, Universitas Negeri Semarang, Semarang, Indonesia \\ Email: atrisyuliarti@students.unnes.ac.id
}

\begin{tabular}{r} 
Informasi Artikel \\
\hline Diterima $:$ 14-12-2021 \\
Revisi $: 26-12-2021$ \\
Diterbitkan $:$ 20-01-2022 \\
\\
Keywords: \\
\hline Critical Thinking \\
Education Quality
\end{tabular}

\begin{abstract}
Abstrak
Critical thinking atau berpikir kritis adalah kemampuan berpikir yang ada pada diri peserta didik. Kemampuan ini membantu peserta didik menghadapi setiap permasalahan dengan menggunakan pemikiran ilmiah. Berpikir kritis terdiri dari kata berpikir dan kritis, menurut KBBI berpikir adalah menggunakan pikiran untuk mempertimbangkan dan memutuskan sesuatu, sedangkan kritis dimaknai dengan sifat tidak mudah percaya, selalu berusaha menemukan masalah, dan ketajaman dalam menganalisis. Banyak pendapat ahli yang menjelaskan pengertian critical thinking. Namun, pengertian berpikir kritis dapat disimpulkan sebagai kemampuan berpikir manusia dengan menggunakan pemahaman yang fokus dan mendalam hingga menemukan titik terang yang pasti. Penggunaan critical thinking dapat menyelesaikan permasalahan dalam kehidupan, tidak terkecuali permasalahan dalam pendidikan di Indonesia. Hal itu karena berpikir kritis memiliki ciri menyelesaikan masalah dengan kesimpulan yang sistematik dan berargumen benar. Dengan pemberian solusi dari hasil pemikiran kritis, maka permasalahan pendidikan mampu terselesaikan. Apabila masalah pendidikan terselesaikan dan dengan mempertimbangkan beberapa hal, maka mutu pendidikan akan perlahan meningkat.
\end{abstract}

Kata Kunci: Critical Thinking, Mutu Pendidikan

\section{PENDAHULUAN}

Pada saat ini, kemampuan berpikir kritis merupakan salah satu kemampuan yang harus dikembangkan oleh setiap masyarakat, tidak terkecuali dalam lingkup sekolah. Dalam bidang pendidikan, critical thinking sangat penting untuk diterapkan. Namun dalam pengaplikasiannya istilah ini masih dianggap hal asing bagi masyarakat terutama bagi para peserta didik dan pendidik. Masih banyak sekolah yang belum mengajarkan kemampuan berpikir kritis dalam kegiatan belajar mengajar. Kemampuan berpikir kritis yang tinggi, mampu membawa seseorang menghadapi masalah dengan solusi yang cemerlang. Maka dari itu, berpikir kritis merupakan kemampuan yang perlu dikembangkan lebih lanjut. 
Critical thinking atau berpikir kritis bukan hanya menjelaskan pemikiran manusia, dalam berpikir kritis juga terdapat proses belajar, kekuatan dalam berpikir, dan juga sikap tidak mudah percaya. Menurut Angelo (1995) berpikir kritis adalah mewujudkan pemikiran yang logis, pemikiran kritis yang tinggi, dengan cara menganalisis, mengenal, menggabungkan, mendalami permasalahan serta cara memecahkannya, serta membuat simpulan serta evaluasi terkait suatu masalah. Selain itu, pendapat Johnson (2010) menjelaskan bahwa kemampuan berpikir dengan baik merupakan kemampuan berpikir kritis, dan bagian dari berpikir dengan baik adalah dengan mendalami cara berpikir dengan baik. Kemampuan berpikir kritis perlu dikembangkan sejak peserta didik masih berada di pendidikan sekolah dasar dan pendidikan lain setingkatnya.

Menurut Facione (dalam Filsaime, 2008) menyebutkan terdapat 6 keahlian dalam berpikir kritis yang utama dalam berpikir kritis dalam sebuah masalah. Keahlian tersebut adalah interpretasi, analisis, evaluasi, inference (kesimpulan), penjelasan, dan regulasi diri. Keenam keahlian tidak sekaligus diajarkan kepada peserta didik, kecakapan perlu diajarkan satu-persatu untuk memperoleh pemikiran kritis yang maksimal.

Pemikiran kritis perlu diterapkan baik untuk peserta didik maupun pendidik, dengan penerapan model pembelajaran yang bermaksud meningkatkan kemampuan berpikir kritis dalam setiap pembelajaran yang diberikan, maka tujuan pembelajaran itu sendiri akan mudah terwujud. Dengan tujuan yang sudah terwujud, mutu pendidikan di Indonesia akan lebih mudah meningkat.

Mutu pendidikan adalah kualitas yang harus dicapai dalam melaksanakan kegiatan pendidikan di sekolah dalam suatu negara. Menurut KBBI mutu adalah ukuran baik atau buruk suatu benda, kualitas, taraf atau derajat. Sedangkan pendidikan adalah proses pengubahan sikap dan tata laku seseorang atau kelompok orang dalam usaha mendewasakan manusia melalui upaya pengajaran dan pelatihan; proses, cara, dan perbuatan mendidik. Dapat disimpulkan bahwa mutu pendidikan sangat penting dalam menentukan kualitas pendidikan suatu negara. Selain itu, mutu pendidikan yang baik akan mengantarkan suatu negara ke arah yang lebih maju.

\section{PEMBAHASAN}

\section{Pengertian Critical Thinking}

Critical thinking merupakan suatu pemahaman yang awalnya tidak diketahui oleh masyarakat, namun belakangan ini pemahaman terhadap berpikir kritis mulai disorot terutama di dalam kegiatan belajar mengajar. Mengutip jurnal "Peningkatan Kemampuan Berpikir Kritis Pada Siswa Sekolah Dasar" yang ditulis oleh Bilqis Waritsa Firdausi, Warsono, dan Yoyok Yermiandhoko dalam jurnal tersebut menjelaskan pentingnya menanamkan kemampuan berpikir dalam diri peserta didik terutama lingkup pendidikan sekolah dasar. Kemampuan berpikir kritis perlu dikembangkan sejak anak berusia dini terutama sejak anak masuk sekolah dasar. Jika dikembangkan, kemampuan berpikir kritis akan melatih peserta didik untuk memiliki kemampuan menganalisis dan memberikan evaluasi terkait informasi atau pendapat sebelum menentukan apakah ia akan menerima atau menolak informasi tersebut. Oleh karena itu, pendidikan di sekolah harus mampu mengajarkan kemampuan peserta didik untuk berpikir kritis (Susanti et al., 2019). Namun, realitanya kemampuan berpikir kritis peserta didik di Indonesia masih tergolong rendah dan dibutuhkan peningkatan kemampuan berpikir kritis melalui pembelajaran.

Ada beberapa ahli yang menjelaskan pengertian critical thinking atau kemampuan berpikir kritis ini. Yang pertama menurut Beyer dalam Zubaidah (2010) berpendapat bahwa kriteria yang digunakan untuk menilai suatu kualitas, dari kegiatan yang dilakukan sehari-hari sampai kegiatan menyusun kesimpulan dari sebuah tulisan yang digunakan untuk mengevaluasi kebenaran yang pasti seperti pernyataan-pernyataan, ide-ide, argumen-argumen, penelitian dan lainnya.

Yang kedua menurut Ennis (1996), berpikir kritis adalah berpikir yang memiliki alasan tertentu dan reflektif dengan menekankan pada pembuatan keputusan tentang apa yang harus dipercayai atau dilakukan. Ada beberapa keterangan berpikir kritis yang berasal dari aktivitas kritis menurut Ennis (1996) ada 5 yaitu seorang yang bisa berpikir kritis, mampu merumuskan pokok-pokok permasalahan, selain itu pemikir kritis mampu memberikan fakta yang dibutuhkan untuk menyelesaikan suatu masalah, berpikir kritis juga dibuktikan dengan kemampuan memilih argumen yang logis, relevan, dan akurat, orang yang berpikir kritis dapat menemukan ide terbaik berdasarkan sudut pandang yang berbeda, dan yang terakhir seseorang yang mampu berpikir kritis, dapat menentukan akibat dari suatu pernyataan yang diambil sebagai suatu keputusan.

Yang ketiga menurut Jumaisyaroh, dkk (2015: 88) beliau menyatakan kemampuan berpikir kritis adalah kemampuan sesesorang untuk berpikir efektif yang mendukung seseorang untuk menilai, serta mengambil kesimpulan untuk memutuskan tentang apa yang ia pahami dan ia lakukan. 
Dari pemahaman ketiga ahli yang sudah dipaparkan, dapat disimpulkan bahwa berpikir kritis adalah kemampuan berpikir yang diyakini dan dilakukan seseorang dalam menentukan keputusan yang logis dan dapat ditemukan bukti yang valid. Pemikiran kritis tidak bisa dilakukan secara asal-asalan karena harus melalui pemahaman yang teruji kebenarannya. Pemikiran kritis juga perlu memperhatikan beberapa hal seperti mengidentifikasi permasalahan yang ada dengan cermat dan tidak menelan informasi tanpa disaring terlebih dahulu.

\section{Mutu Pendidikan Indonesia Saat ini}

Mutu pendidikan adalah kualitas pendidikan yang ada dalam sebuah negara. Mutu pendidikan biasanya digunakan untuk mengukur maju atau tidaknya sebuah program pendidikan di negara terkait. Mutu pendidikan adalah tingkat kecerdasan kehidupan suatu bangsa yang ikut mendorong majunya pendidikan suatu negara. Mutu pendidikan adalah kadar pendidikan dari suatu negara. Kadar pendidikan bisa dirumuskan menjadi 2 pokok yaitu apa yang dihasilkan dan siapa yang memakai pendidikan tersebut.

COVID-19 yang saat ini mempengaruhi kehidupan di Indonesia maupun di dunia menyebabkan beberapa sektor kehidupan mengalami hambatan tidak terkecuali dalam pendidikan. Mutu pendidikan Indonesia yang awalnya masih dibilang relatif rendah, saat adanya pandemi ini mutu pendidikan di Indonesia semakin merosot. Hal itu diketahui dari penjelasan Kemendikbud dalam final cetak yang membahas "Sistem Penjaminan Mutu Pendidikan". Dalam penjelasannya memperoleh pengetahuan bahwa mutu pendidikan Indonesia hingga saat ini tepatnya sebelum pandemi berlangsung, mutu pendidikan Indonesia tergolong rendah jika dibandingkan dengan negara-negara tetangga. Peringkat Indonesia rendah karena implementasi standar nasional belum dilakukan secara maksimal. Indra Charismiadji yaitu Direktur Eksekutif Center of Education Regulations and Development Analysis mengatakan, mutu pendidikan Indonesia pada masa pandemi mengalami penurunan, memberikan pendapat bahwa keadaan pendidikan saat ini rendah karena tidak sesuai dengan desain pembelajaran yang dibuat oleh Ki Hajar Dewantara. Keadaan yang dimaksud adalah keadaan dalam keluarga atau rumah, masyarakat, dan sekolah.

Kualitas pendidikan di Indonesia memprihatinkan, UNESCO (2000) menjelaskan beberapa data tentang peringkat Human Development Index, menuliskan bahwa pengembangan manusia di Indonesia menurun. Di antara 174 negara di dunia, Indonesia menempati urutan ke-102 pada tahun 1996, urutan ke-99 pada tahun 1997, urutan ke-105 pada tahun 1998, dan urutan ke-109 pada tahun 1999. Selain data tersebut, menurut survei Political and Economic Risk Consultant (PERC), kualitas pendidikan di Indonesia berada di urutan ke-12 dari 12 negara di Asia. Data yang diperoleh dari The World Economic Forum Swedia (2000) mengatakan bahwa Indonesia memiliki daya saing yang rendah, karena menempati urutan ke-37 dari 57 negara yang disurvei di dunia. Dari data yang sudah dipaparkan, dapat disimpulkan bahwa tingkat pendidikan di Indonesia masih tergolong rendah.

Mutu pendidikan yang rendah, tentu tidak hanya muncul begitu saja. Ada beberapa faktor yang mendorong mutu pendidikan di Indonesia menurun atau rendah. Kurangnya sarana dan prasarana yang berkualitas. Indonesia memiliki beberapa daerah yang masih tertinggal, baik dalam akses transportasi maupun akses pendidikan. Daerah yang biasa disebut daerah 3T itu, masih banyak mengalami kesulitan karena tidak adanya akses yang memadai dalam keadaan beraktivitas, termasuk dalam akses menuntut ilmu. Tidak hanya daerah $3 \mathrm{~T}$ banyak sarana belajar di hampir daerah di Indonesia yang mengalami kerusakan, kepemilikan media belajar yang rendah, laboratorium tidak memadai, bahkan banyak daerah yang tidak memiliki gedung sendiri. Penyebab lain adalah rendahnya kualitas pendidik, pendidik di beberapa daerah Indonesia masih belum memiliki profesionalisme yang memadai dalam melaksanakan tugasnya sebagaimana terangkum di pasal 39 UU Nomor 20 tahun 2003. Dalam UU tersebut dijelaskan bahwa pendidik harus bisa merencanakan pembelajaran, melaksanakan pembelajaran, menilai hasil pembelajaran, melakukan bimbingan, melakukan pelatihan, melakukan penelitian dan melakukan pengabdian masyarakat. Namun, tugas-tugas tersebut masih belum bisa dicapai oleh sebagian daerah di Indonesia.

\section{Korelasi Critical Thinking dengan Mutu Pendidikan}

Diungkapkan oleh Darmina Pratiwi (2016) menyatakan bahwa "Berpikir kritis adalah kemampuan untuk bernalar dalam suatu cara yang terorganisasi. Berpikir kritis memungkinkan untuk memanfaatkan potensi dalam melihat masalah, memecahkan masalah, menciptakan dan menyadari diri." Dalam mengikuti sebuah proses pembelajaran terkadang terdapat peserta didik yang belum maksimal atau belum berhasil dalam belajar. Ada 2 faktor yang menentukan seseorang berhasil atau tidak dalam belajar yaitu faktor internal dan faktor eksternal. Salah satu faktor internal yang mempengaruhi keberhasilan peserta didik dalam menguasai materi pembelajaran salah satunya adalah intelegensi, menurut seorang psikolog, Donald Stener, intelegensi adalah kemampuan seseorang menggunakan pengetahuan yang sudah dimiliki untuk membantu memecahkan suatu masalah. Salah satu bentuk intelegensi adalah kemampuan berpikir kritis. Berpikir kritis berkaitan dengan pemikiran bahwa berpikir merupakan peluang pada manusia yang perlu dikembangkan agar kemampuan yang dimiliki bergerak secara optimal. Berdasarkan hal ini peserta didik akan memiliki Lisensi: Creative Commons Attribution 4.0 International (CC BY 4.0) 
rasa ingin tahu yang sangat besar dan mencoba memecahkan masalahnya. Setiap orang memiliki tingkat berpikir yang berbeda-beda.

Kemampuan berpikir kritis yang berbeda antar peserta didik akan membuat hasil belajar atau pemahaman peserta didik terhadap suatu pembelajaran akan berbeda pula. Apabila peserta didik memiliki kemampuan berpikir kritis yang kurang, peserta didik tersebut cenderung lebih sulit untuk memecahkan masalah dalam pembelajaran. Sementara peserta didik yang memiliki tingkat kemampuan berpikir kritis yang tinggi akan dapat menerima pembelajaran yang diberikan dengan baik dan menguasai materi pembelajaran secara optimal. Oleh karena itu, berpikir kritis sangat dibutuhkan dalam meningkatkan mutu pendidikan, karena apabila sebagian besar peserta didik di Indonesia mampu untuk menguasai kemampuan berpikir kritis, maka peserta didik tersebut akan lebih mudah memahami pembelajaran di sekolah. Materi yang mampu dipahami oleh banyak peserta didik, akan mempermudah peserta didik dalam meraih prestasi. Dengan prestasi yang dicapai oleh peserta didik, akan membantu meningkatnya mutu sekolah, dengan mutu sekolah yang tinggi di sebagian besar daerah Indonesia, maka dapat dipastikan mutu pendidikan Indonesia juga meningkat.

Sebuah negara akan dinilai unggul mutu pendidikannya apabila sebagian peserta didik yang ada dapat unggul atau memahami materi-materi yang ada dalam sekolah. Selain memahami materi, peserta didik juga harus mampu menerapkan materi tersebut dalam bentuk sebuah prestasi. Semakin banyaknya generasi muda yang mampu mencetak prestasi baik dalam maupun luar negeri, mampu membuat kualitas pendidikan meningkat. Mutu pendidikan yang meningkat tidak hanya ditinjau dari prestasi peserta didik, namun mutu seorang pendidik juga perlu untuk digapai. Pendidik yang mampu memberikan pembelajaran secara rinci, jelas, dan mudah dipahami dapat mendorong peserta didik menjadi lebih lancar dalam menggunakan kemampuan berpikir kritis. Menggunakan media pembelajaran yang tepat juga mampu meningkatkan kemampuan berpikir kritis seperti media model SOLE (Self Organized Learning Environment).

\section{Pentingnya Menguasai Kemampuan Critical Thinking}

Keterampilan berpikir kritis sangat penting bagi peserta didik karena membantunya untuk menghadapi persaingan di era global ini. Kemampuan berpikir ini harus dikembangkan melalui kegiatan belajar. Kemampuan berpikir adalah kemampuan untuk menggabungkan pikiran seseorang dan melihatnya dengan cermat. Keterampilan berpikir kritis sangat penting karena membantu untuk memahami apa yang mereka lihat, bagaimana mereka melihat dunia dan bagaimana mereka berinteraksi dengan orang lain. Berpikir kritis memungkinkan seseorang menganalisis pemikirannya untuk memastikan pilihan yang telah dibuat adalah yang terbaik dan paling logis untuk digunakan. Mereka yang terbiasa berpikir kritis memahami dan mempercayai apa yang mereka katakan sehingga mereka tidak kebingungan dengan masalah yang akan mereka hadapi di kemudian hari.

Menurut April (2015), ia berpendapat bahwa berpikir kritis memungkinkan seseorang untuk memiliki banyak alternatif jawaban dan ide-ide kreatif dalam membantu untuk berpikir secara mandiri dan spontan. Pikiran dan tindakan reflektif adalah tindakan dan pemikiran yang tidak dapat direncanakan dan dilaksanakan dengan refleks. Dengan membiasakan berpikir kritis, ada banyak cara untuk memilih jawaban dan ide-ide kreatif. Ketika dihadapkan pada suatu masalah, orang yang kritis memiliki banyak pilihan untuk memecahkan masalah, daripada hanya terpaku pada satu solusi. Berpikir kritis memungkinkan peserta didik memiliki banyak ide kreatif, inovatif dan unik. Berpikir kritis juga dapat mengajarkan penyelesaian suatu masalah dengan menggunakan sudut pandang yang lain, sehingga solusi yang didapatkan tidak tergantung pemikiran satu pihak saja, namun dari beberapa pihak. Dengan menggunakan sudut pandang orang banyak, solusi yang didapatkan akan lebih relevan dan menjadi langkah penyelesaian yang terbaik karena tidak membela satu pihak saja. Bukan hanya itu, dengan menggunakan sudut pandang orang lain, peserta didik dengan kemampuan berpikir kritis tidak mudah menghakimi pendapat orang lain.

Pemecahan masalah, berpikir kritis, kreatif, sistematis dan logis adalah di antara berbagai jenis keterampilan yang harus dimiliki peserta didik untuk menghadapi perkembangan global (Indarti, 2013). Pandangan ini juga didukung oleh perspektif Sumarmi (2013) yang menyatakan bahwa berpikir kritis merupakan salah satu keterampilan untuk masa depan yang harus dimiliki setiap peserta didik. Ketika keterampilan ini berkembang lebih jauh, peserta didik akan terbiasa berpikir kritis. Situasi belajar akan membantu peserta didik mampu menciptakan lingkungan yang mendorong kemampuan untuk berpikir terbuka dan luwes, tanpa takut mengungkapkan gagasannya, dan tanpa malu mengungkapkan apa yang diinginkannya. Situasi belajar yang dihasilkan harus memfasilitasi diskusi, mendorong seseorang untuk mengungkapkan ide atau pendapat.

\section{Meningkatkan Kemampuan Critical Thinking Melalui Metode Pembelajaran}

Upaya pembelajaran pertama dapat dilakukan dengan menggunakan metode scaffolding. Metode scaffolding adalah implementasi berdasarkan konsep Vygotsky dalam mendefinisikan zona pengembangan 
yang berdekatan (zona pengembangan terdekat). Lebih khusus lagi, menurut Vygotsky, pendekatan ini mengasumsikan bahwa pembelajar memiliki dua tahap perkembangan: perkembangan aktual dan perkembangan potensial. Menurut Vygotsky, perkembangan nyata terjadi ketika individu menggunakan kemampuan kognitifnya secara mandiri. Berikutnya adalah potensi peningkatan. Perkembangan ini adalah tingkat mental yang dapat dicapai oleh seorang anak (dalam hal ini peserta didik) dengan bantuan orang dewasa, seperti guru, orang tua, atau teman yang lebih berbakat. Psikis adalah kemampuan untuk berpikir, memahami dan mengeksplorasi nilai-nilai dan hal-hal di sekitar seseorang. Dengan metode scaffolding, guru dapat bekerja sama dengan peserta didik untuk membantu mereka memperdalam pengetahuan mereka dengan berbicara, mengajukan pertanyaan, dan berbicara dengan rekan kerja. Dengan cara ini, peserta didik dilatih untuk berpikir kritis. Misalnya, ketika melakukan kegiatan diskusi, peserta didik harus menggunakan bukti yang kuat dan ide-ide logis untuk memastikan bahwa kegiatan diskusi berjalan lancar dan menghasilkan hasil terbaik. Kriteria pembelajaran scaffolding dianggap berhasil apabila peserta didik berhasil tanpa bantuan lebih lanjut, ketika peserta didik berhasil dengan bantuan orang lain, dan ketika peserta didik berhasil.

Upaya pembelajaran lain yang dapat mengembangkan berpikir kritis adalah pemecahan masalah. Pendekatan ini memastikan penerapan metode pengajaran yang fokus pada pembelajaran dan keterampilan pemecahan masalah yang kreatif, diikuti dengan pengembangan kapasitas. Memecahkan masalah kreatif adalah bagian dari pemikiran analitis dan imajinasi peserta didik. Untuk mengembangkan kemampuan belajar dan kreativitas peserta didik, guru harus didorong untuk mengambil tugas yang diberikan kepada mereka. Pembelajaran berbasis masalah kreatif menghubungkan objek dalam situasi kehidupan nyata, menyatukan peserta didik dengan pengalaman sehari-hari dan mengembangkan kemungkinan kreatif. Ketika peserta didik berada dalam situasi yang sulit, mereka menggunakan keterampilan pemecahan masalah mereka untuk memilih dan merumuskan ide-ide mereka, membiasakan diri untuk menghasilkan ide-ide, dan memungkinkan mereka untuk berpikir lebih umum. Untuk menerapkan pembelajaran ini, proses pembelajaran perlu fokus pada banyak hal, seperti penciptaan nilai, komunikasi, konstruksi, analisis, berpikir kritis dan kreatif, pembelajaran komunitas, dan penggunaan penilaian positif.

Upaya lain yang dapat dilakukan untuk membuat peserta didik berpikir kritis adalah dengan menggunakan pembelajaran yang baik pada masalah tersebut atau problem based learning. Menurut DIRJEN DIKTI (2006), konsep pembelajaran berbasis masalah didasarkan pada metode pembelajaran yang menggunakan masalah nyata dalam konteks di mana peserta didik belajar melalui keterampilan berpikir kritis dan pemecahan masalah. Untuk melakukan apa yang diperlukan. Subjek. Melalui pembelajaran berbasis masalah, peserta didik akan menghadapi tantangan nyata dalam kehidupan sehari-hari dalam rangka meningkatkan pengetahuannya (Fateh Rahman, 2015). Kemandirian dan harga diri peserta didik meningkat melalui penggunaan berpikir kritis dalam kehidupan sehari-hari mereka (Arends, 2012). (Marlena, 2017; Hussein, 2017; Weibov, 2016) mengemukakan bahwa pembelajaran yang buruk pada masalah dapat meningkatkan kemampuan berpikir kritis dan hasil belajar kognitif peserta didik. Apabila metode-metode belajar tersebut mampu dilaksanakan dengan baik, bukan hanya kemampuan berpikir kritis peserta didik saja yang berkembang, namun kualitas pendidikan di Indonesia juga ikut meningkat. Hal itu karena metode yang disebutkan tidak hanya menanamkan cara berpikir kritis, namun juga sebagai sarana kegiatan belajar mengajar antara peserta didik dan pendidik. Jika tujuan metode dilakukan dengan benar, maka tujuan metode tersebut akan diraih dengan maksimal.

\section{KESIMPULAN}

Dalam kesimpulan tidak boleh ada referensi. Kesimpulan berisi fakta yang didapatkan, cukup menjawab Mutu pendidikan dapat ditingkatkan melalui kemampuan berpikir kritis yang dikuasai oleh peserta didik. Kemampuan berpikir kritis yang mumpuni, membuat peserta didik yang mempunyai keterampilan ini akan lebih unggul dari yang lain. Kemampuan berpikir kritis juga berguna untuk memahami setiap materi pelajaran yang diberikan. Menguasai mata pelajaran merupakan salah satu faktor penentu tingkat kualitas pendidikan. Oleh sebab itu, peserta didik di Indonesia sudah seharusnya bisa menguasai keterampilan berpikir kritis, yang tujuannya untuk membantu majunya mutu pendidikan di Indonesia. Critical thinking adalah kemampuan berpikir kritis yang seharusnya dikembangkan oleh setiap individu. Berpikir kritis dihasilkan melalui pemikiran yang dilakukan secara mendalam dan pemikiran tersebut diyakini oleh orang yang bersangkutan. Pemikiran kritis bersifat reflektif atau spontan, sehingga untuk mendapatkan pemikiran yang terbaik diperlukan adanya pelatihan secara terus menerus.

Ada beberapa metode pembelajaran yang bisa digunakan untuk mengembangkan pemikiran kritis sekaligus meningkatkan mutu pendidikan. Metode tersebut apabila dimanfaatkan dengan baik maka hasil yang diberikan akan maksimal. Untuk menggunakan metode secara efektif, diperlukan kerjasama antar pihak 
yang terkait, seperti pendidik dan peserta didik. Agar memiliki pemikiran yang kritis dan meningkatnya mutu pendidikan, juga dibutuhkan metode yang sesuai. Oleh karena itu, peserta didik maupun pendidik dapat menganalisis metode mana yang sesuai dengan pendapat kedua belah pihak.

\section{REFERENCES}

[1] A. P. K. HARAHAP, "Faktor Faktor Yang Mempengaruhi Berpikir Kritis.” 2019, doi: 10.31219/osf.io/jywdh.

[2] R. Ambarsarie, PENGAJARAN BERPIKIR KRITIS. 2017.

[3] M. Tanjung, "Kemampuan berpikir kritis matematika," no. May, 2019.

[4] M. Pandemi, B. Nadeak, C. P. Juwita, and E. Sormin, "Korelasi Kemampuan Berpikir Kritis Mahasiswa dan Penggunaan Media Sosial Hubungan kemampuan berpikir kritis mahasiswa dengan penggunaan media sosial terhadap capaian pembelajaran pada masa pandemi Covid-19," no. September, 2020, doi: 10.29210/146600.

[5] M. Y. Anggraeni and I. K. A. Putra, "Korelasi Antara Kemampuan Berpikir Kritis dengan Penguasaan Kompetensi Pengetahuan IPS,” vol. 3, no. 1, pp. 79-88, 2019.

[6] A. History, "No Title," vol. 1, no. Snpd, pp. 742-750, 2018.

[7] J. Dunstan and S. Cole, “Critical Thinking,” 2021, pp. 85-98.

[8] B. W. Firdausi, Y. Yermiandhoko, and U. N. Surabaya, "PENDAHULUAN Kemampuan berpikir kritis pada siswa sekolah dasar merupakan hal yang wajib dikembangkan. Hal ini dikarenakan melalui kemampuan berpikir kritis akan melatih siswa untuk mencermati , menganalisis dan mengevaluasi informasi atau pendapat sebelu," vol. 11, no. 2, pp. 229-243, 2021.

[9] E. Ekadiansyah, "Peran Literasi dalam Pengembangan Kemampuan Berpikir Kritis The Role of Literacy in the Development of Critical Thinking Abilitie," vol. 1, no. 1, pp. 23-33, 2020.

[10] F. A. Islam and U. M. Palu, "Faktor Penyebab Rendahnya Kualitas Pendidikan dan Cara Mengatasinya ( Studi pada : Sekolah Dasar di Desa Tonggolobibi ) Factors Causing the Low Quality of Education and How to Overcome It ( Study on : Elementary School in Tonggolobibi Village ),” vol. 16, 2021.

[11] P. R. Ningsih, A. Hidayat, and S. Kusairi, "Penerapan Problem Based Learning untuk Meningkatkan Kemampuan Berpikir Kritis dan Hasil Belajar Siswa Kelas III,” no. 2012, pp. 1587-1593, 2018.

[12] Z. N. Resty and N. Mufti, "Discovery Learning Berbantuan Schoology: Upaya Peningkatan Kemampuan Berpikir Kritis," no. 2007, pp. 267-273, 2019. 